\title{
Assessment of non-wood forest products trade competitiveness between Ethiopia and Asia/19 countries
}

\author{
Ahmed Nuru Zelekea,* (iD
}

\begin{abstract}
The study makes a comparative analysis of Ethiopia and Asia/19 countries in the foreign trade of non-wood forest products between the periods of 2008-2018. The study focused on two commodity groups with the Harmonized System (HS) codes; of HS409: (Natural honey); and HS130190: (Natural Gums, resins, gum Arabic, and oleoresins). Revealed Comparative Advantage Index, Relative Export Advantage Index, Relative Import Advantage Index, and Relative Trade Advantage Index were used to assess the competitive advantage of Ethiopia in non-wood forest products foreign trade over Asian/19 countries. At the same time, Cross Relative Export Advantage and Cross Relative Import Advantage indicators were employed to test the competitiveness of Ethiopia and Asian/19 countries in the foreign trade of non-wood forest products. The study findings show that Ethiopia has experienced a comparative advantage both in a relative export and import advantage in the trade of non-wood forest products over the study period as compared to Asia/19 countries.

Keywords: Asia, Comparative advantage, Ethiopia, International competitiveness, Non-wood forest products trade
\end{abstract}

\section{Etiyopya ve Asya/19 ülkeleri arasındaki odun dışı orman ürünleri ticaretinin rekabetçilik değerlendirmesi}

\begin{abstract}
Özet: Bu çalışma, 2008-2018 dönemleri arasındaki odun dışı orman ürünleri dış ticaretinde Etiyopya ve Asya/19 ülkelerinin rekabet gücünü analiz etmektedir. Çalışma, uyumlaştırılmış (HS) kodları sistemine sahip iki ayrı emtia grubu HS409: Doğal bal; HS130190: Doğal Zamklar, reçineler, Arap zamkı ve oleoresinler baz alınarak gerçekleştirilmiştir. Etiyopya'nın Asya/19 ülkeleriyle odun dışı orman ürünleri dış ticaretinde mukayeseli üstünlüğünü değerlendirmek için, Açıklanmış Karşılaştırmalı Üstünlük Endeksi, Göreli İhracat Avantaj1 Endeksi, Göreli İthalat Avantaj1 Endeksi ve Göreli Ticaret Avantaj1 Endeksi kullanılmıştır. Aynı zamanda, Etiyopya'nın Asya/19 ülkeleri ile odun dışı orman ürünlerinin dış ticaretindeki rekabet gücünü incelemek için Göreli İhracat Avantajı ve Göreli İthalat Avantajı göstergeleri kullanılmıştır. Çalışmanın bulgularına göre, Asya/19 ülkelerine kıyasla, Etiyopya'nın odun dışı orman ürünlerinin ticaretinde, çalışma dönemi boyunca hem göreli ihracat hem de ithalat avantajı açısından karşılaştırmalı bir avantaj yaşadığı görülmektedir.

Anahtar kelimeler: Asya, Karşılaştırmalı Üstünlük, Etiyopya, Uluslararası rekabet, Odun dışı orman ürünleri ticareti
\end{abstract}

\section{Introduction}

Forest products are important for economic activities all over the world (Aiyeloja et al., 2012). Forests are multifunctional natural resources, providing different products to people living in this world. Accordingly, forest products are grouped into two major categories: Timber and non-timber forest products (NTFPs) collected from the forest (Berhanu, 2019). NTFPs are useful substances, materials, or commodities obtained from forests without the harvesting process of trees (Sacande and Parfondry, 2018). NTFPs have sustained rural families for centuries globally and are prominent among internationally traded commodities for long periods (Aiyeloja et al., 2012). Now, they are, more widely, viewed as crucial for sustainable forest use, providing benefits for local communities and offering an important means for development of countries, especially in drylands. Many NTFPs have significant economic potential for developing countries (Sacande and Parfondry, 2018).
In Ethiopia, NTFPs contribute significantly to the total household income of rural people, the national economy and ecosystem stability, and environment (Baye, 2015; Berhanu, 2019). Non-timber forest products are important sources of livelihood in many rural areas of Ethiopia. For instance, Honey is one of the main NTFPs used as a cash crop by the majority of the rural population in Ethiopia. Of the total honey production Ethiopia, more than half (50-60\%) of the produce is used in the production of local beverage called Tej (honey wine), $20 \%$ is consumed at the household level used as table honey, and only a small portion of the product is marketed. Cash generated from the sale of honey provides an opportunity of supplementing income earning for the farmers. For example, in the southwestern parts of Ethiopia on average, households own $20-30$ beehives. Five to six kilograms of honey is harvested from each hive, and the total annual harvest of a household reaches $100-200 \mathrm{~kg}$ of honey (Berhanu, 2019). The income obtained from the sale of gum and resin was estimated to contribute to $32.6 \%$ of annual household subsistence and ranks second after

\footnotetext{
$\triangle$ a Ethiopian Environment and Forest Research Institute, Forest Products Innovation Research, P.O Box: - 1832 Hawassa, Ethiopia

@ * Corresponding author (İletişim yazar1): manem880@gmail.com

$\checkmark \quad$ Received (Geliş tarihi): 15.02.2021, Accepted (Kabul tarihi): 21.05.2021
}

Citation (Atıf): Zeleke, A.N., 2021. Assessment of non-wood forest products trade competitiveness between Ethiopia and Asia/19 countries. Turkish Journal of Forestry, 22(2): 105-110. DOI: $\underline{10.18182 / \mathrm{tjf} .880850}$ 
livestock in the overall household livelihood contributions to rural households in Ethiopia (Ahmed, 2013). According to Berhanu (2019), gum and resin are essential components of livelihood activities for the rural people in dryland areas, for the collection, taping, and grading of gum and resin demands a large number of labor. Therefore, it provides seasonal job opportunities for rural people. The quality of NTFPs is different, that low quality is utilized at a household level and high quality products enter local, regional and international markets (Berhanu, 2019).

The growing participation of developing countries in world trade over the past thirty years has been one of the most important developments (Negussie and Dessalegn, 2014). Asia is a major contributor for this growing participation, which has been facilitated by diversification of exports (Negussie, 2015). He also states that foreign trade has increasingly become a basis of economic prosperity in many countries of the world, both export and import trades are equally important though. Many developing countries have to work to increase their experience in international trade. Ethiopia, as a developing country, has limited its export to few primary products, which are mainly agricultural commodities and somehow NTFPs. Ethiopia's total exports have been growing at an average rate of 15.23 percent during the years 1970/71 to 2010/11 (Belayneh and Wondaferahu, 2013). Ethiopia is the leading Honey producer in Africa, and the tenth largest honey-producing countries in the world (Tekeba and Yeshitela, 2018). According to Tekeba and Yeshitela (2018), the Ethiopian main market for honey is traditional honey wine (Tej) making, which does not require high-quality honey. The market for honey in Ethiopia is generally not well developed, mainly due to a limited number of buyers compared to the number of producers. Ethiopia is the leading honey producer in Africa, and in order for it to have quality honey production for the export purpose, it is better to know the potential. Additionally, the focus must be on its competitiveness against the 19 main importer Asian countries. The Gums and Resins market in Ethiopia plays an important role in the daily life of many Ethiopians, these products contribute a lot to the national economy of Ethiopia. For instance, during 2001-2010, Ethiopia exported about 11,247 tons of gums and resins and generated USD $24,208,760$. The list of main importers included China and the United Arab Emirates with a share of about $20 \%$ and $19 \%$, respectively (Zenebe et al., 2013). However, the major gum producing species are declining both in terms of size (deforestation) and quality of stands (degradation) at an alarming rate. The decline is also associated factors such as expansion of crop and livestock production as well as human settlement, overgrazing, fuel-wood \& charcoal production, and anthropogenic fire and traditional harvest (Semegnew et al., 2018). Focusing on the potential of the country and studying the competitiveness of Ethiopia against the biggest 19 Asian importer countries of gum and resin product will serve the purpose of giving an insight for policy makers and different stakeholders working on this area.

The forestry sector plays several important economic roles by earning foreign currency mainly from the export of non-timber forest products, and by providing environmental services that support the sustainable operation of other sectors. The most important NTFPs that generate substantial income for rural households and foreign currency earnings in Ethiopia are coffee, honey, and natural gums and resins (Kilawe and Habimana, 2016).

Asia is both the largest market for Ethiopian exports and accounts for about $36 \%$ of total exports, also the dominant supplier of Ethiopian imports with a share of about $65 \%$ (Gebrehiwot and Gebru, 2015). Asia is the region to where much of Ethiopian NTFPs are exported. Asia receives more than $57 \%$ of Ethiopian NTFPs followed by Africa which receives about $15 \%$ of the Ethiopian forest product export (Baye, 2015). This makes it paramount for the country to assess the international competitiveness of the non-timber forest products market so as to maximize the trade potential in the Asian market. Based on the relative sources of export receipts in Asia in 2012, China took the lead by providing about $\$ 320.66$ million, followed by Saudi Arabia with \$190.92 million and United Arab Emirates, Japan, Israel, Pakistan, and India with $\$ 78.3$ million, $\$ 74.54$ million, $\$ 67.18$ million, $\$ 45.70$ million, and $\$ 42.42$ million respectively. More than 20 percent of the import payment on goods in 2012 originated from China, followed by Saudi Arabia and India accounting for about $14 \%$ and $9 \%$ of the total imports expenditure respectively. Kuwait, Japan, Indonesia, United Arab Emirates, Rep. of Korea, Malaysia, and Thailand account $6.05 \%, 3.72 \%, 2.93 \%, 2.44 \%, 1.72$ $\%, 1.59 \%$, and $1.4 \%$ respectively. There is also a great potential for imports from countries such as Hong Kong and Singapore (Alekaw, 2016). The data obtained from the UN Comtrade database on honey and gum and resin non-wood forest products shows that Ethiopia has more import and export relation with 19 Asian countries from all other Asian countries.

The main purpose of the study is, therefore, to assess the competitiveness of Ethiopia with the selected Asian countries in the foreign trade of non-wood forest products. And aimed to measure the competitive advantage of the non-wood forest product sector in Ethiopia between the periods of 2008-2018 over the selected Asian countries.

\subsection{Competitiveness and comparative advantage}

Assessing the international competitiveness of countries and identifying the main factors affecting international performance is important for formulating effective policies to maintain, adjust, or enhance market positions (Maksymets and Lönnstedt, 2016). The concept of competitiveness in classical international economic theory is the same as the competitive advantage, which is linked to the macroeconomic concept of competitiveness of a nation (Maksymets and Lönnstedt, 2016; Hoang et al., 2017). Comparative advantage and its principle are important and the oldest concept to economic theory (Vollrath, 1991). The measure of competitiveness and comparative advantage on the scope of forest-based sectors was determined with the help of the number of prominent quantitative indices such as Ratio Of Net Exports Index, Export-Import Ratio Index, The Relative Export Advantage Index, The Relative Import Penetration Index, The Relative Trade Advantage Index, Rate Of Export Shares Index, and Intra Industry Trade Index (Müftüoğlu and Kayacan, 2019). Magezi and Okan (2019) observed that the concept of comparative advantage could be attributed to a situation where a country has a relatively low cost of goods compared to other countries. However, the international competitiveness of trade refers to a nation securing and maintaining an advantage in trade 
compared to the rest of the world. Kara et al. (2019) state that, competitive advantage is manifested by a situation where a country should specialize in the export of certain categories of goods and services and import others. Competitiveness is the ability to provide products more effectively and efficiently compared to their competitors and to stay in business to have the capacity to exploit existing market opportunities and generate new markets (Sasatani, 2009).

According to Durand and Giorno (1987), there are three basic criteria that a perfect measure of international competitiveness should satisfy. The perfect measure should cover all of the sectors exposed to competition (represent all traded goods that are subject to competition and only those goods); it should encompass all of the markets open to competition; and it should be constructed from data that are fully comparable internationally. The measurement of competitiveness differs depending on whether it is undertaken for the purpose of policy analysis within a specific country, or is used for international comparisons of the business environment (Eckhard, 2006). On the measure of international competitiveness, researches have extensively investigated that product quality determines export performance, price competitiveness as a value for money, service quality, and relationship with importers or trust (Masnat et al., 2010). Siggel (2006) states that calculating comparative advantage using the Balassa (1965) index of 'Revealed Comparative Advantage' (RCA) is common in the empirical trade literature. It reflects the success of exporting countries relative to a worldwide standard. Vollrath (1991) observes that the Relative Trade Advantage (RTA) index takes into account both export and import statistics.

The concept of revealed comparative advantage (RCA) is grounded in conventional trade theory and calculated by using the Balassa (1965) index of 'Revealed Comparative Advantage' (Fertö and Hubbard, 2003). This approach shows the success in exporting countries relative to a worldwide standard (Magezi and Okan, 2019). Due to the importance of international competitiveness, diverse indices have been developed to assess it. Such indices include the Revealed Comparative Advantage (RCA), Relative Export Advantage (RXA), Relative Import Advantage (RMA), Relative Trade Advantage (RTA), Relative Competitiveness (RC), and Cross-Country Indexes of Relative Competitiveness (CRC) (Maksymets and Lönnstedt, 2016).

Various authors have applied a combination of these indices for examining competitiveness of countries internationally. For example, Hoang et al. (2017) using the Relative Export Advantage (RXA), Relative Import Advantage (RMA), Relative trade advantage (RTA), analyzed the competitive advantages of Vietnam's agricultural sectors. Manying and Xiaohong (2017) also used the trade competitiveness index (TC) and revealed comparative advantage index (RCA) indices to study the Competitiveness of Financial Services Trade between China and the countries along "One Belt, One Road". Magezi and Okan (2019) applied Revealed Comparative Advantage (RCA), Relative Export Advantage (RXA), Relative Import Advantage (RMA), Relative Trade Advantage (RTA) Cross Relative Competitiveness (CRC), Cross Relative Export Advantage (CRXA), and the Cross Relative Import Advantage (CRMA) indices to assess Competitiveness of forest products trade between Turkey and the European Union countries.

\section{Materials and methods}

\subsection{Materials}

The study focuses on the non-wood forest products trade between Ethiopia and the nineteen Asian countries (Bahrain, China, Hong Kong SAR, India, Indonesia, Israel, Japan, Jordan, Kuwait, Malaysia, Oman, Pakistan, Qatar, Rep. of Korea, Saudi Arabia, Singapore, Thailand, United Arab Emirates, and Vietnam). These countries are selected because they have great import-export relation with Ethiopia basically on honey, gum \& resin, and other non-wood forest products. The data set contained the annual imports and exports nominal values in the US dollar from the trade of non-wood forest products between Ethiopia and Asian/19 countries from the years 2008 to 2018. The data was obtained from the UN Comtrade database (United Nations, 2019) of the Harmonized System Codes (HS 2019) of two commodity groups HS409: Natural honey; HS130190: Natural Gums, resins, gum Arabic, oleoresins.

\subsection{Methods}

Where $X_{i j}$ is the volume or value of exports of product $i$ by country $j, X_{r j}$ is the volume or value of exports of all products by country $j, X_{\text {is }}$ the volume or value of exports of product $i$ by country $j$ to all countries of the world (or region), $\mathrm{X}_{\mathrm{rs}}$ is the total volume or value of world exports of the product. $\mathrm{M}_{\mathrm{ij}}$ is the volume or value of imports of product $\mathrm{i}$ into country $\mathrm{j}, \mathrm{M}_{\mathrm{rj}}$ is the volume or value of imports of all products to country $j, M_{i s}$ the volume or value of imports of product $\mathrm{i}$ to country $\mathrm{j}$ from all countries of the world (region), and $\mathrm{M}_{\mathrm{rs}}$ is the volume or value of total world imports. $X_{\mathrm{ik}}$ is the volume or value of exports of product $i$ by country $\mathrm{k}$, and $\mathrm{X}_{\mathrm{rk}}$ is the volume or value of all exports of all products by country $\mathrm{k} . \mathrm{M}_{\mathrm{ik}}$ is the volume or value of imports of product $\mathrm{i}$ into country $\mathrm{k}$, and $\mathrm{M}_{\mathrm{rk}}$ is the volume or value of imports of all products to country $\mathrm{k}$. As competitiveness is a relative measure and should only be applied for comparative purposes, it is important to use two Cross-Country Indices of Relative Competitiveness (Table 1). 
Table 1. Index's to assess the competitiveness of Ethiopia with Asia/19 countries in non-wood forest product trade

\begin{tabular}{|c|c|c|c|c|}
\hline No & Name of Index & Formula & Reference & Remark \\
\hline 1. & $\begin{array}{l}\text { Revealed } \\
\text { Comparative } \\
\text { Advantage (RCA) }\end{array}$ & $B=\frac{X_{i j} / X_{r j}}{X_{i s} / X_{r s}}$ & Balassa (1965) & $\begin{array}{l}\text { A value greater than } 1 \text { indicates there is a } \\
\text { comparative advantage of the trade in the focal } \\
\text { product. }\end{array}$ \\
\hline 2 & $\begin{array}{l}\text { Relative Export } \\
\text { Advantage (RXA) }\end{array}$ & $R X A=$ & $\begin{array}{l}\text { Magezi, H.E. and } \\
\text { Okan, T., (2019) }\end{array}$ & $\begin{array}{l}\text { A value greater than } 1 \text { indicates that the country has } \\
\text { an export advantage in the focal commodity. }\end{array}$ \\
\hline 3 & $\begin{array}{l}\text { Relative Import } \\
\text { Advantage (RMA) }\end{array}$ & $R M A=\frac{M_{i j} / M_{r j}}{}$ & $\begin{array}{l}\text { O. Maksymets and L. } \\
\text { Lönnstedt, (2016) }\end{array}$ & $\begin{array}{l}\text { A value less than } 1 \text { indicates that a country has an } \\
\text { import Advantage. }\end{array}$ \\
\hline 4 & $\begin{array}{l}\text { Relative Trade } \\
\text { Advantage (RTA) }\end{array}$ & $R T A=R X A-R M A$ & Vollrath, (1991) & $\begin{array}{l}\text { A positive value of RTA is an indication of } \\
\text { comparative advantage. }\end{array}$ \\
\hline 5 & $\begin{array}{l}\text { Cross Relative } \\
\text { Export Advantage } \\
\text { (CRXA) }\end{array}$ & $C R X A=\frac{X_{i j} / X_{r j}}{X_{i k} / X_{r k}}$ & $\begin{array}{l}\text { O. Maksymets and L. } \\
\text { Lönnstedt, (2016) }\end{array}$ & $\begin{array}{l}\text { A value greater than } 1 \text { indicates that the country has } \\
\text { an advantage in the export of the commodity. }\end{array}$ \\
\hline 6 & $\begin{array}{l}\text { Cross Relative } \\
\text { Import Advantage } \\
\text { (CRMA) }\end{array}$ & $C R M A=\frac{M_{i j} / M_{r j}}{M_{i k} / M_{r k}}$ & $\begin{array}{l}\text { Magezi, H.E. and } \\
\text { Okan, T., (2019) }\end{array}$ & $\begin{array}{l}\text { A value less than } 1 \text { indicates that there is a } \\
\text { comparative advantage in the import of a } \\
\text { commodity. }\end{array}$ \\
\hline 7 & $\begin{array}{l}\text { Cross Relative } \\
\text { Competitiveness } \\
\text { (CRC) }\end{array}$ & $\operatorname{lnCRC}=\operatorname{lnCRXA}-\operatorname{lnCRMA}$ & $\begin{array}{l}\text { O. Maksymets and L. } \\
\text { Lönnstedt, (2016) }\end{array}$ & $\begin{array}{l}\text { lnCRC > } 0 \text { reveal a comparative/competitive } \\
\text { advantage in the target market. }\end{array}$ \\
\hline
\end{tabular}

\section{Results and discussion}

Ethiopia appears to have experienced an advantage in the export of HS409 and HS130190 non-wood forest products on the Asian/19 countries market from the period of 2008 to 2018 with mean values of 2.59 and 2.65 for RCA and RXA respectively. Concerning its progress, both the values of RCA and RXA indices have increased over the past 11 years but decreased in 2018. The decline was due to the political crisis and unrest in the country. Accordingly, the import and export of the country was very much affected by the unrest. Besides, Ethiopia has experienced an advantage in the import of non-wood forest products of HS409 and HS130190 for the past 11 years. This implies a relative import advantage in the trade of non-wood forest products with RMA value of less than 1. Ethiopia has experienced a comparative trade advantage in non-wood forest products over the Asian/19 markets, for it has experienced a positive value of RTA index over the study period (Figure 1).

Only countries such as India (with mean value 2.28), Pakistan (with mean value 1.13), and Vietnam (with mean value 2.06) have an average RCA greater than one over the study period, from 2008-2018 and have experienced a comparative advantage in trade of non-wood forest products market. Ethiopia also has experienced a comparative advantage in the trade of non-wood forest products market with a mean value of 2.59 (Table 2).

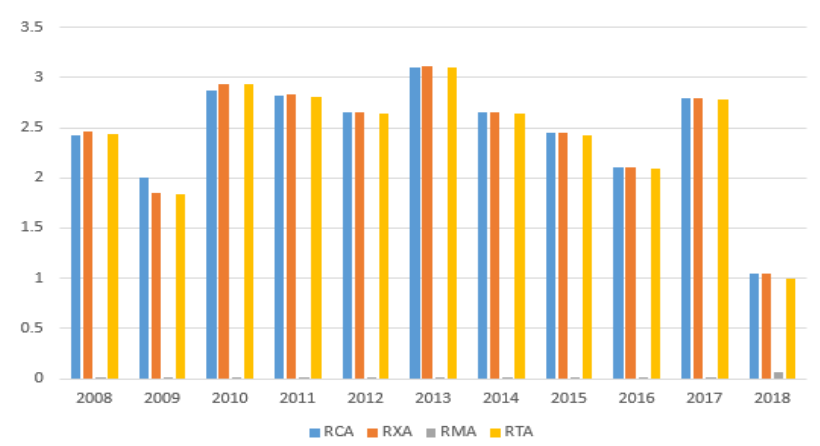

Figure 1. Ethiopia's RCA, RXA, RMA and RTA in nonwood forest products trade with Asian/19 countries

Table 2. Mean RCA, RXA, RMA, and RTA of Ethiopia and Asian/19 countries in non-wood forest products trade

\begin{tabular}{lcccr}
\hline Country & RCA & RXA & RMA & \multicolumn{1}{c}{ RTA } \\
\hline Bahrain & 0.020 & 0.020 & 0.140 & -0.12 \\
China & 0.050 & 0.040 & 0.130 & -0.09 \\
Hong Kong SAR & 0.050 & 0.050 & 0.250 & -0.20 \\
India & 2.280 & 2.340 & 0.880 & 1.46 \\
Indonesia & 0.830 & 0.830 & 0.320 & 0.51 \\
Israel & 0.020 & 0.020 & 0.300 & -0.28 \\
Japan & 0.004 & 0.004 & 0.660 & -0.65 \\
Jordan & 0.290 & 0.290 & 0.900 & -0.61 \\
Kuwait & 0.020 & 0.020 & 1.040 & -1.02 \\
Malaysia & 0.140 & 0.140 & 0.370 & -0.23 \\
Oman & 0.190 & 0.190 & 0.010 & 0.18 \\
Pakistan & 1.130 & 1.130 & 0.400 & 0.73 \\
Qatar & 0.004 & 0.004 & 0.004 & 0 \\
Rep. of Korea & 0.004 & 0.004 & 0.070 & -0.06 \\
Saudi Arabia & 0.340 & 0.340 & 0.230 & 0.11 \\
Singapore & 0.170 & 0.160 & 0.380 & -0.22 \\
Thailand & 0.830 & 0.830 & 0.290 & 0.54 \\
United Arab Emirates & 0.090 & 0.090 & 0.430 & -0.34 \\
Vietnam & 2.060 & 2.040 & 0.250 & 1.79 \\
Ethiopia & 2.590 & 2.650 & 0.200 & 2.58 \\
\hline
\end{tabular}


In Table 2, compared to Ethiopia, the experience of the majority of the countries revealed export disadvantage of the non-wood forest products market having a mean RXA of below one. However, the export advantage of India, Pakistan, and Vietnam had a mean value of $2.34,1.13$, and 2.04 respectively. On the other hand, Japan, Qatar, and the Republic of Korea experienced the least mean RXA value of 0.004, which was similar across these five countries, between the periods of 2008-2018. Ethiopia experienced a high mean value of RXA 2.65 over eleven years. This shows that Ethiopia had the greatest export advantage compared to the 19 Asian countries. All countries in Asia/19 experienced a mean RMA of below one except Kuwait with a mean value of 1.04 over the study period. This indicates that the majority of the countries and Ethiopia had a relative import advantage in importing non-wood forest products except Kuwait over the study period. Qatar, the Republic of Korea, Oman, China, and Bahrain had a relative import advantage in importing non-wood forest products with a mean value of RMA $0.004,0.01,0.07,0.13$, and 0.14 respectively.

Countries like India (1.46), Indonesia (0.51), Oman (0.18), Pakistan (0.73), Saudi Arabia (0.11), Thailand (0.54), and Vietnam (1.79) had a positive mean RTA value over the study period which implies a comparative advantage in the trade of non-wood forest products. The rest countries, except for Qatar, experienced a negative mean RTA value. Qatar with RTA mean value of zero (0) was at a break-even point neither with trade advantage nor trade disadvantage on non-wood forest products. Ethiopia also experienced a comparative advantage with a positive RTA mean value of 2.58 in the non-wood forest product market (Table 2).

Ethiopia had an export advantage with a high mean value of CRXA over all the Asian/19 countries in the nonwood forest product market over the study period of 20082018. This advantage is greater than the advantage of China, Hong Kong SAR, Bahrain, Israel, and Kuwait, with a CRXA of 47.4, 47.4, 18.84, 18.84, and 16.6 respectively. On the other hand, Ethiopia had the least advantage over Japan (6.64) and Rep. of Korea (6.65) over the study period. Generally, Ethiopia was more advantageous on non-wood forest products (honey and gum \& resin) over the selected Asian countries. Regarding relative import advantage, Ethiopia experienced an import advantage over fourteen countries. Specifically, Ethiopia has experienced a high advantage over Saudi Arabia, India, Jordan, and Japan with CRMA of $0.09,0.23,0.22$, and 0.29 respectively. However, it experienced a relative import disadvantage over five countries' non-wood forest product markets- Bahrain (1.43), China (1.38), Oman (2.5), Qatar (5), and the Republic of Korea (2.77). The result, thus, shows that Ethiopia should strive to overcome the import disadvantage over these five Asian countries. The cross relative competitiveness which is natural $\operatorname{logs}$ of $\operatorname{lnCRC}$ was calculated and Ethiopia showed more competitiveness than all countries. On the other hand, the result of $\operatorname{lnCRC}$ showed that countries like Oman (0.53), Qatar (0.23), and Rep. of Korea (0.38) had small mean values compared to the rest 16 Asian countries. Nonetheless, Ethiopia remained competitive where lnCRC is a positive value. This indicates that Ethiopia had great competitiveness over Asian/19 countries in non-wood forest products over the study period (Table 3 ).
Table 3. CRXA, CRMA, and lnCRC of Ethiopia with Asia/19 countries in non-wood forest products trade.

\begin{tabular}{lrcc}
\hline Country & CRXA & CRMA & lnCRC \\
\hline Bahrain & 18.84 & 1.43 & 1.09 \\
China & 47.40 & 1.38 & 1.55 \\
Hong Kong SAR & 47.40 & 0.78 & 1.78 \\
India & 11.37 & 0.23 & 1.69 \\
Indonesia & 13.18 & 0.62 & 1.77 \\
Israel & 18.84 & 0.66 & 1.45 \\
Japan & 6.64 & 0.29 & 1.36 \\
Jordan & 8.56 & 0.22 & 1.58 \\
Kuwait & 16.60 & 0.91 & 1.93 \\
Malaysia & 14.45 & 0.54 & 1.42 \\
Oman & 8.38 & 2.50 & 0.53 \\
Pakistan & 11.06 & 0.50 & 1.34 \\
Qatar & 8.40 & 5.00 & 0.23 \\
Rep. of Korea & 6.65 & 2.77 & 0.38 \\
Saudi Arabia & 7.50 & 0.09 & 1.91 \\
Singapore & 15.40 & 0.51 & 1.47 \\
Thailand & 8.18 & 0.67 & 1.08 \\
United Arab Emirates & 15.75 & 0.46 & 1.52 \\
Vietnam & 12.50 & 0.81 & 1.18 \\
\hline
\end{tabular}

The author shares the statement of Semegnew et al. (2018) that "one of the benefits delivered by non-wood forest products is foreign currency earning through export". Therefore, the result shows that Ethiopia was more beneficial and earned foreign currency in non-wood forest products than these selected Asian countries. Asia is the best destination for Ethiopia's export of non-wood forest products. The result implies that Ethiopia should maximize its trade potential in the non-wood forest product market over the selected Asian countries.

\section{Conclusion}

This study is aimed at assessing non-wood forest products foreign trade competitiveness between Ethiopia and Asian/19 countries. The empirical findings revealed that Ethiopia experienced a comparative advantage both in relative export and import advantage in the trade of nonwood forest products over the study period. The study findings revealed that Ethiopia had a strong comparative advantage over the Asian/19 countries in terms of trade of non-wood forest products.

The results confirmed that most of the countries' experience revealed both import and export disadvantage of non-wood forest products market compared to Ethiopia. The findings also revealed that, in relation to relative trade advantage (RTA), Ethiopia experienced a comparative advantage with a positive value, while the majority of Asia/19 countries experienced a negative RTA value. This positive RTA mean value gives a good picture of Ethiopia's position over the non-wood forest product market. The study finding suggested that Ethiopia has shown great competitiveness over Asia/19 countries in non-wood forest products over the study period in terms of cross relative competitiveness, and Ethiopia should go forward over 19 Asian countries for the future concerning cross relative competitiveness.

In the years to come, Ethiopia should strive to maintain full advantage of competitiveness both in export and import over Asia/19 countries by promoting its export of non-wood forest products, which may have a significant role in the economic development of the country in the long-run and 
improving the export competitiveness of the non-wood forest product market. In addition to these findings, there are some areas that the study had not addressed on other nonwood forest products (like coffee, khat, spices, etc.) competitiveness that could be studied in future research. Therefore, I suggest that future researches need to focus on the in-depth analysis of non-wood forest products (like coffee, khat, spices, etc.) market competitiveness, which would give an insight to policymakers on how to improve the competitiveness of Ethiopia over Asian countries. Generally, this study provides interesting results that may help stakeholders and policymakers to obtain a clearer view on how to improve Ethiopia's Non-wood forest products trade with the Asian countries.

\section{References}

Ahmed, M.A., 2013. Contribution of non-timber forest products to household food security: The case of Yabelo Woreda, Borana zone, Ethiopia. The International Institute for Science, Technology and Education (IISTE), 20: ISSN 2225-0557.

Aiyeloja, A.A., Oladele, A.T., Ezeugo, O.E., 2012. Evaluation of non-timber forest products trade in Ihiala Local Government Area, Anambra State, Nigeria. International Journal Of Science and Nature, 3(2): 366-372. ISSN 2229-6441.

Alekaw, K.Y., 2016. Determinants and Potentials of Foreign Trade in Ethiopia: A Gravity Model Analysis. No. 74509. https://mpra.ub.uni-muenchen.de/74509/ (Accessed: 15.01.2021)

Balassa, B., 1965. Trade liberalization and revealed comparative advantage. Manchester School of Economics and Social Studies, 33(2): 99-123. ISSN 1467-9957.

Baye, B., 2015. Status and trends of major non-timber forest products trade in Ethiopia. Research Journal of Agriculture and Environmental Management, 4(4): 197-201. ISSN 2315-8719.

Belayneh, K.A., Wondaferahu, M.D., 2013. Determinants of export performance in Ethiopia: Var model analysis. ABHINAV National Monthly Refereed Journal of Research in Commerce \& Management, 2(5): 94-109. ISSN 2277-1166.

Berhanu, D.G., 2019. Review of Economic contribution of nontimber forest products (NTFPs) for rural livelihoods and its potential for sustainable forest management in Ethiopia. Agricultural Research \& Technology Open Access Journal, 21(5): 214-215. ISSN 2471-6774. DOI: 10.19080/ARTOAJ.2019.21.556179.

Durand, M., Giorno, C., 1987. Indicators of international competitiveness: Conceptual aspects and evaluation. OECD Economic and Studies, 9: 147-182.

Eckhard, S., 2006. International Competitiveness and comparative advantage: A survey and a proposal for measurement. Journal of Industry, Competition and Trade, 6: 137-159. DOI 10.1007/s10842-006-8430-x.

Fertö, I., Hubbard, L., 2003. Revealed comparative advantage and competitiveness in Hungarian agri-food sectors. World Economy, 26(2): 247-259. DOI 10.1111/1467-9701.00520.

Gebrehiwot, G., Gebru, B., 2015. Ethiopia's foreign trade potential: Inferences from a dynamic gravity approach. International Journal of Economics and Business Research, 9(4): 355-375. DOI: 10.1504/IJEBR.2015.069667.

Hoang, V.V., Tran, K.T., Tu, B.V., 2017. Assessing the agricultural competitive advantage by the RTA index: A case study in Vietnam. AGRIS on-line Papers in Economics and Informatics, 9(3): 15-26. ISSN 1804-1930. DOI 10.7160/aol.2017.090302.

Kara, O., Şahin, Ö., Bekar, İ., Kayacan, B., 2019. International competitiveness analysis of industrial wood and wood products sector: The case of Turkey. The International Journal of Economic and Social Research, 15(1): 1306 - 2174.
Kilawe, E., Habimana, D., 2016. Forestry contribution to national economy and trade in Ethiopia, Kenya and Uganda. Food and Agriculture Organization of the United Nations, Addis Ababa, pp. 6-8.

Magezi, H.E., Okan, T., 2019. Competitiveness analysis of forest products trade between Turkey and European Union countries. Turkish Journal of Forestry, 20(4): 366-372. DOI: $10.18182 / \mathrm{tjf} .630250$.

Maksymets, O., Lönnstedt, L., 2016. International competitiveness: A case study of American, Swedish, and Ukrainian forest industries, The International Trade Journal, 30(2): 159-176. DOI 10.1080/08853908.2016.1138910.

Manying, H., Xiaohong, D., 2017. A comparative analysis of the competitiveness of financial services trade between China and the countries along "One Belt, One Road". Journal of Emerging Issues in Economics. Finance and Banking (JEIEFB) an Online International Research Journal, 6(2): 2317-2333. ISSN 2306-367X.

Masnat, A.H., Bashir, A.Z., Amer, J., 2010. Competitive capacity determinants for Jordanian exports of selected fruits and vegetables in Arab gulf markets. Dirasat, Agricultural Sciences, 37(1):9-23.

Müftüoğlu, G.İ., Kayacan, B., 2019. An analysis of foreign trade competitiveness of the forest-based sector in Turkey. Turkish Journal of Forestry, 20(1): 41-49. DOI: 10.18182/tjf.514745

Negussie, Z., 2015. Determinants of Ethiopian trade performance to its bordering region: A gravity model approach. Journal of Natural Sciences Research, 5(11): 39-45. ISSN 2225-0921.

Negussie, Z., Dessalegn, G., 2014. Determinants of bilateral trade between Ethiopia and its major trading partners': A gravity model approach. Journal of Economics and Sustainable Development, 5(15): 82-88. ISSN 2222-2855.

Sacande, M., Parfondry, M., 2018. Non-timber forest products from restoration to income generation, FAO, Rome, pp. 40. ISBN 978-92-5-131118-9 License: CC BY-NC-SA 3.0 IGO

Sasatani, D., 2009. National Competitiveness Index of The Forest Products Industry in The Asia pacific Region. FAO United Nations Regional Office for Asia and the Pacific. Bangkok.

Semegnew, T., Teshome, S., Tesefaye, B., Abreham, B., Getachew, A., 2018. Production and challenges of gum Arabic in Ethiopia: Review. Journal of Natural Sciences Research, 8(24): ISSN 2225-0921

Siggel, E., 2006. International competitiveness and comparative advantage: A survey and a proposal for measurement. Journal of Industry, Competition and Trade, 6(2): 137-159.

Tekeba, N., Yeshitela, E., 2018. Review of Ethiopia's global position in honey and other bee products production and marketing: Analysis of sectoral opportunities and limitations. Biomedical Journal of Scientific \& Technical Research (BJSTR), 10(3): 7879-7883 DOI: $10.26717 /$ BJSTR.2018.10.001969.

United Nations, 2019. UN Comtrade Database - International Trade Statistics - Import/Export Data. http://comtrade.un.org, Accessed: 23.12.2019

Vollrath, T.L., 1991. A theoretical evaluation of alternative trade intensity measures of revealed comparative advantage. Weltwirtschaftliches Archiv, 127(2): 265-280. DOI 10.1007/BF02707986.

Zenebe, M., Adefires, W., Temsgen, Y., Tinsae, B., Trehas, M., Demel, T., 2013. Economic contribution of gum and resin resources to household livelihoods in selected regions and the national economy of Ethiopia. Ethnobotany Research \& Applications, 11: 273-288. 